\title{
The Role of path Metaphors in Conceptualising Life IN ENGLISH AND SERbIAN: A Corpus-based Analysis
}

\begin{abstract}
The aim of this paper is to obtain insight into crosslinguistic similarities and differences in English and Serbian regarding the conceptualisation of life via components related to motion along a path. This is accomplished by studying the extended meanings of a set of English and Serbian lexemes associated with departure, passage through intermediate path points, arrival and the space along which the motion occurs, using randomly selected examples from the representative corpora of the two languages. Since a common focus in cognitive linguistic studies has been on the metaphor LIFE IS A JOURNEY, we show that there is an equally important case of life being conceptualised as a trajector in both languages, which testifies to the phenomenon of metaphor duality. In addition, the direction of the movement also serves as an important factor in structuring various aspects of life and its related concepts.
\end{abstract}

Keywords

Path; LIFE; conceptual metaphors; contrastive analysis; English; Serbian

\section{Introduction}

Following seminal works in the field of cognitive linguistics (e.g. Lakoff and Johnson (2003[1980]); Johnson 1987; Lakoff 1987 etc.), the link between language and conceptualisation has been one of the major topics in linguistics in the past three decades. Cognitive linguists argue that conceptual structure is derived from embodiment, i.e. that "the nature of our embodiment determines and delimits the range and nature of concepts that can be represented" (Evans and 
Green 2006: 176). As a cognitive mechanism, conceptual metaphor has received a lot of attention due to its vital role in shaping abstract experience and much has been written on the ways of interpreting conceptual metaphors as means that "provide rich evidence about the ways in which some aspects of our lived experience are associated with others, for reasons that reflect basic aspects of perception, thought, and possibly neurological organization" (Grady 2007: 188). This is achieved through metaphor as "a pattern of conceptual association" (Grady 2007: 188), a set of mappings established between a concept in the source domain, wellelaborated and more accessible to everyday experience, and a concept in the target domain, less clearly delineated, with mappings being "systematic metaphoric correspondences between loosely related ideas" (Grady 2007: 190).

Due to its pervasiveness and significance, human experience with motion is surely one of the most thoroughly studied source domains in cognitive linguistics. The relevance of the experience with motion in the conceptualisation of abstract concepts has been demonstrated both by linguistic and psycholinguistic studies, using various methods in different languages (e.g. Filipović 2007; Johansson Falck 2010; Matlock et al. 2005; Radden 1996; 2004; Özçalişkan 2005; Vesić Pavlović 2014). The focus of this paper is on the conceptualisation of life via the experience with motion along a path in English and Serbian. In the literature, a well-known conceptual metaphor LIFE IS A JOURNEY has been mentioned most frequently in this respect, described as "one of the most powerful tools we have for making sense of our lives and for making decisions about what to do and even what to believe" (Lakoff and Turner 1989: 65). However, there are very few studies that explore the conceptualisation of life via motion using linguistic corpora, especially ones that point to crosslinguistic similarities and differences in this regard (such as Özçalişkan 2003a). As noted elsewhere, there is a need to test the systematicity of metaphors proposed by the conceptual metaphor theory using representative corpora (Johansson Falck 2016) and to see the extent to which the patterns observed in one language can be found in another (Johansson Falck 2016). Thus, our focus will be on the extended meanings of a set of lexemes originally denoting path components in English and Serbian in order to explore the presence of the LIFE IS A JOURNEY metaphor using examples excerpted from the representative corpora of the two languages. A systematic examination of the examples collected from the corpora may show that the same elements of the experience with motion provide fertile ground for certain other metaphors for structuring life and life events, within or besides the well-elaborated metaphor LIFE IS A JOURNEY. Hence, the aims of the present study are the following: to identify aspects of the conceptualisation of life via motion along a path in English and Serbian, to identify the metaphors underlying the structuring of life and to explore the crosslinguistic similarities and differences, based on a qualitative analysis of the examples. In the following section, we will first elaborate on the importance of experience with motion and paths and provide an overview of the previous relevant studies on the conceptualisation of life via motion along a path. 


\section{The concept of path and the present study}

A path may be described as "a directed stretch of space, typically the trajectory or orbit along which an object moves" (Zwarts 2005: 743). It is also a pervasive, well-structured and well-understood image schema (Johnson 1987), "a recurring, dynamic pattern of our perceptual interactions and motor programs that gives coherence and structure to our experience" (Johnson 1987: xiv).

The important features of the path that serve as foundations for structuring an array of abstract concepts include its starting point or source, its ending point or goal and a series of locations connecting the starting point with the ending point (Johnson 1987: 113-114). Other important elements include a moving trajector, the actual trajectory of motion, the position of the trajector at a certain time, the direction of the trajector at that time, the actual final location of the trajector, the speed of motion, a vehicle etc. (Lakoff and Johnson 1999: 33). Traversing a path is performed from a starting point towards an end point, with the purpose of reaching a destination. Research has confirmed that this may lead to asymmetry between goal and source paths in both language and memory, with preference given to endpoints, i.e. goals over sources (Lakusta and Landau 2005; Lakusta and Landau 2012; Papafragou 2010). The entailments of moving along a path are featured in the metaphor system of EVENT STRUCTURE METAPHOR, which consists of the following submetaphors: STATES ARE LOCATIONS, CHANGES ARE MOVEMENTS, CAUSES ARE FORCES, ACTIONS ARE SELF-PROPELLED MOVEMENTS, PURPOSES ARE DESTINATIONS, MEANS ARE PATHS (TO DESTINATIONS), DIFFICULTIES ARE IMPEDIMENTS TO MOTION, EXPECTED PROGRESS IS A TRAVEL SCHEDULE, EXTERNAL EVENTS ARE LARGE, MOVING OBJECTS and LONG TERM, PURPOSEFUL ACTIVITIES ARE JOURNEYS (Lakoff 1993). The conceptual mapping LIFE IS A JOURNEY is one of the most frequently mentioned examples of the LONG TERM, PURPOSEFUL ACTIVITIES ARE JOURNEYS metaphor. This mapping relies on the JOURNEY scenario (Lakoff 1993), which is realised via the subdomains of MOTION and PATH that emerges from goaloriented motion along a path (Silaški and Đurović 2014).

Considering the complexity of the experience with motion along a path, we selected certain components of the path and the lexemes that denote them in order to obtain an insight into how the total experience of moving on a path from the starting point towards a destination is transferred into the realm of structuring LIFE. Additionally, we aimed at selecting words which denoted similar concepts in both English and Serbian. It is pointed out in the literature that verbs of motion specify the roles of the bearer of motion and the path of motion, while directional prepositions specify the "geometric characteristics of the path" (Eschenbach et al. 2000: 143). Hence, we chose to include verbs of motion, directional prepositions and nouns denoting the space along which motion occurs.

The following PATH schema components were included: moving away from the starting point (represented by the English preposition from and the Serbian $o d$, as well as by the English verbs go away and depart and the Serbian otici $i$ and krenuti), moving through the intermediate points of the path (represented by the 
English preposition through and the verbs go and pass, as well as the Serbian preposition kroz and the verbs ići and proći), approaching and reaching a destination (represented by the English prepositions to and towards and the verbs come and arrive, and the Serbian prepositions do, prema and ka and the verbs doć $i$ and stici $i$ ), and the space along which motion occurs (the English nouns path and road and the Serbian staza and $p u t$ ).

In order to empirically test the occurrence of structuring life via the elements of motion along a path, we used representative corpora as the source of data. A number of researchers (e.g. Deignan 1999; Gibbs 2007; Kövecses 2008; Stefanowitsch and Gries 2006; Steen 2007) point to the fact that early metaphor research did not pay much attention to defining the strict criteria for establishing linguistic manifestations of the conceptual metaphor and used non-representative data based on the author's intuition, which consequently led to unreliable conclusions. Corpus methodology in conceptual metaphor research may thus help towards "generating a reliable description of the typical context and use of linguistic metaphors" (Cameron and Deignan 2003: 150). Discussing the advantages of using corpora in studying meaning and conceptualisation, Deignan (1999: 177) has argued that "the study of large corpora can give information about the frequency and use of linguistic metaphors which is otherwise difficult to assess". Therefore, patterns of use may be detected more quickly and accurately (Deignan 1999: 178).

The linguistic corpora used in this study were the British National Corpus $(B N C)^{1}$ for English and the Corpus of the contemporary Serbian language 2013 of the Faculty of Mathematics of the University of Belgrade ${ }^{2}$ for Serbian. Data were collected as a part of a more extensive study dealing with the metaphorical mappings of the PATH schema in English and Serbian (Vesić Pavlović 2015). Data were randomly excerpted from the corpora, i.e. for each of the previously mentioned lexemes, and out of the total number of examples recorded in the corpora, a random $10 \%$ was selected and further analysed. The metaphor identification procedure proposed by the Pragglejaz group (2007) was used to identify instances in which the lexemes were used metaphorically and, further, used so as to structure life and related concepts. This process of selection yielded 437 examples in English and 457 in Serbian, and this corpus of examples was utilised to draw conclusions in the present study. Although the fact that research has been performed on the representative corpora of the two languages makes quantification possible, the focus of the study is a qualitative analysis of the examples.

\section{Life as a journey in different languages}

The majority of previous studies exploring the conceptualisation of life via motion focused on the LIFE IS A JOURNEY metaphor. It has been emphasised frequently that this conceptualisation is closely related to that of TIME, since "understanding the events of one's life as constituting the points of a path (...) necessitates 
creating a COURSE OF LIFE slot in the LIFE domain" (Lakoff and Turner 1989: 63). Klikovac (2006) has argued that the mapping A PERSON IS A TRAVELLER THROUGH HIS/HER LIFE is a submetaphor of the PERSON IS A TRAVELLER THROUGH TIME metaphor, where the time units through which a person moves are parts of his/her life (Klikovac 2006: 156). This suggests that existence is motion from one point of time to another, whereby the past remains behind the person, and the future is in front, i.e. A PERSON MOVES DUE TO HIS/HER EXISTENCE FROM THE PAST INTO THE FUTURE (Klikovac 2004: 121).

Lakoff and Turner (1989) have thoroughly dealt with several aspects of the LIFE IS A JOURNEY metaphor in English, mentioning a number of correspondences between the domains of LIFE and JOURNEY, such as a person as a traveller, his/ her purposes as destinations, the means of achieving the purposes as routes, difficulties in life as impediments to travel, counsellors as guides, progress as distance travelled, and choices in life as crossroads etc. (Lakoff and Turner 1989: $3)$. Exploring the metaphors for birth and death, they have also formulated the metaphor LIFE IS PRESENCE HERE, which conceptualises life as a cycle with three stages - not being alive, being alive and, finally, being dead, the entailment being that before birth we are absent, during life we are present and after death we are absent again. The conceptual mapping DEATH IS DEPARTURE is observed as an instance of structuring life as being present here; however, death is a specific kind of departure which is one-way, with no return (Lakoff and Turner 1989: 11). Another metaphor for conceptualising death in terms of a journey is DEATH IS GOING TO A FINAL DESTINATION, as an instance of the metaphor CHANGE OF STATE IS CHANGE OF LOCATION ${ }^{3}$.

A previous crosslinguistic study in this field is that by Özçalişkan (2003a), which offered a systematic overview of the metaphors underlying the conceptualisation of LIFE and DEATH via motion verbs in English and Turkish. Özçalişkan (2003a) has established that English and Turkish are similar regarding the presence of the metaphors LIFE IS A MOVING ENTITY/SUBSTANCE, LIFE IS A LOCATION and LIFE IS A JOURNEY. This also applies to the conceptual mappings related to specific aspects of life, such as BIRTH IS ARRIVAL, DEATH IS A MOVING ENTITY, DEATH IS DEPARTURE and DEATH IS A FINAL DESTINATION. Özçalişkan (2003b) has further analysed the metaphors for life and death based on the JOURNEY scenario in Turkish and English. She has noted that the conceptual metaphor LIFE IS A JOURNEY can be additionally specified in Turkish by the journey taking various forms, e.g. a sea voyage, a journey on foot, a walk, and with the human body as a vessel, while the DEATH IS DEPARTURE metaphor in Turkish can also be extended by specifying the means, manner, direction or other features of departure (upwards, downwards, on a boat, on foot). The conceptual metaphor DEATH IS DEPARTURE in Serbian has been explored by Silaški (2011) within a comprehensive study of DEATH metaphors as euphemisms in English and Serbian.

The psychological reality of the LIFE IS A JOURNEY metaphor has been tackled by Katz and Taylor (2008) in their study of human memory, for example, by priming respondents to think of "LIFE" in terms of a course a person follows until 
the age of 70 and asking them to provide a set of events likely to happen to such a person. It turned out that these events were placed sequentially and that there was high agreement about the ages in which the events would occur (Katz and Taylor 2008: 148). Katz and Taylor thus argue that "people conceptualize the life course into a higher-level 'LIFE IS A JOURNEY' metaphor and a set of lower-level conceptual metaphors that inherit the basic structure from the higher-level" (Katz and Taylor 2008: 170). These metaphors would include LOVE IS A JOURNEY, OBTAINING ONE'S INDEPENDENCE IS A JOURNEY, PARENTING IS A JOURNEY etc.

Another aspect of the LIFE IS A JOURNEY metaphor that has been studied closely is that of conceptualising a career as a journey within the journey of life, which is also an instantiation of a higher-level mapping BECOMING INDEPENDENT IS A JOURNEY (Katz and Taylor 2008: 171). Inkson (2002) explored how journey metaphors may be used in understanding careers, focusing especially on the term career path. Smith-Ruig's (2008) experimental study has shown that research participants used metaphoric language relating to journeys, paths and roads to make sense of and conceptualise their career trajectories. Careers were described as journeys, not destinations, with parallel routes, crossroads, turning points etc., and path metaphors occurred spontaneously. Hence, Smith-Ruig (2008: 28) argues that using the JOURNEY or PATH metaphor is beneficial since "it helps to explain and illustrate various career options open to individuals". The results of these studies indicate the relevance of an exploration of the manifestations of LIFE IS A JOURNEY metaphor in two languages and give guidelines for interpreting the obtained findings.

The following section contains the results of the qualitative analysis of the examples extracted from the corpora that pertain to the conceptualisation of LIFE via the selected components of the source domain of MOTION. First, we will elaborate on the instances of LIFE IS A JOURNEY metaphor in the examples excerpted from the corpora, and then proceed with discussing some of the other established mappings that rely on the analysed path components.

\section{PATH metaphors for structuring life in English and Serbian}

The analysis of the examples collected from the corpora has shown that in addition to the case of life being structured as a journey and a person living life as a moving entity, there is another equally important pattern referring to the metaphorically moving life and related concepts (e.g. death, career). This is an instantiation of the phenomenon of metaphor duality, which occurs in metaphorical mappings with motion in space as a source domain where "there is a possibility of reversing figure and ground" (Lakoff and Johnson 1999: 149). It has been previously confirmed in English and Turkish, with life structured metaphorically either as a location, which the person living the life moves in or towards, or as a moving entity (Özçalişkan 2003b). Taking this into account, we will first focus on the case where the moving entity is a person, which includes life being con- 
ceptualised as a location and as a journey. We will discuss various submetaphors that occur within these categories, and then elaborate on cases where life and related concepts are construed as moving entities. Due to limitations of space, only illustrative examples from the analysed data will be presented.

\subsection{LIFE IS A LOCATION}

In the English and Turkish examples analysed by Özçalişkan (2003a), life as a location was typically conceptualised as a bounded space that one can enter, exit, or pass through (Özçalişkan 2003a: 200). Our analysis has also shown that in both English and Serbian life is structured as a location, a space with an entry and exit point, which one may enter or leave, as can be seen in the examples below.

(1) It's strange when people go through life lost to each other.

(2) Volim da kroz život idem sa osmehom.

'I like to go through life with a smile.'

\subsection{LIFE IS A JOURNEY, A PERSON LIVING THE LIFE IS A TRAVELLER}

Consistent with previous studies, in both observed languages, life in its various aspects is conceptualised as a journey: people are trajectors moving on a path of life, encountering various obstacles or other trajectors who they may follow or leave behind. Each sequence of the path of life consists of a number of points that need to be traversed or a traveller can start treading along a new path. There is a timeline from birth to death which extends from the past into the future (Katz and Taylor 2008), which means that the future unfolds "in a linear manner, with the future ahead of us on life's path and the past behind us" (Katz and Taylor 2008:171). Life in general is conceptualised as a road/path, located here and now, with birth as arrival and death as departure, and all important life events as locations along the path of life.

\section{LIFE IS A ROAD/PATH}

Life is conceptualised as a road that a person traverses during his/her existence (LIFE IS A ROAD/PATH). This mapping is linguistically manifested by the English expressions the path of life or the long hard road of life and the Serbian collocations životni put and životna staza, which denote all the events that can happen to a person in life from birth to death.

(3) We've tramped the long hard road of life, sweated and toiled along it.

(4) What do we talk about as we walk the path of life? 
(5) Životni put otpočela je u belokamenoj Moskvi 1850. godine.

'Her path of life started in white-stoned Moscow in 1850.'

(6) Možda se zato za ovaj sport opredeljuju deca koja sama gaze životnom stazom.

'This may be the reason why this sport is chosen by children who tread the path of life on their own.'

Different choices people make in various situations in life lead to different outcomes and hence are conceptualised as paths leading towards different destinations, in keeping with the metaphors MEANS ARE PATHS (TO DESTINATIONS), A DIFFERENT MEANS OF ACHIEVING A RESULT IS A DIFFERENT PATH (Lakoff 1993).

(7) My dear chap, a different path lies before each man and no one of us can tell what road he may chance to follow.

(8) Ali, život je hteo da krenem drugim putem. Morao sam u vojsku [...]. 'However, life has wanted me to tread another road [...].'

In both observed languages, problems in life are structured as obstacles encountered during motion along the path of life, which is the manifestation of the mapping DIFFICULTIES IN LIFE ARE IMPEDIMENTS TO MOTION (Lakoff 1993).

(9) It would be immoral for me to give up on my son; I have been through so much in the last three years, she said.

(10) Posle godinu dana posmatranja, ja se udadoh za njega. Prošli smo kroz velike prepreke.

'After a year, we got married. We went through great obstacles.'

Since life is conceptualised as a path in both English and Serbian, parents are construed as experienced travellers who are supposed to direct their children, i.e. young travellers, towards certain paths as life choices or determine which of a multitude of roads an inexperienced traveller should choose (PARENTS ARE GUIDES ON THE PATH OF LIFE).

(11) Throughout his reign he trod, where day-to-day rule was concerned, in paths already marked out for him by his father, to whom the Enlightenment had meant nothing.

(12) [...] čime su zabrinute majke s manje ili više uspeha pokušavale da zabludele sinove vrate na pravi put.

'[...] the worried mothers, more or less successfully, attempted to bring their lost sons back to the right path.' 
Other people in life are conceptualised as trajectors moving along the same path as the person living life (CLOSE PEOPLE IN LIFE ARE CO-TRAVELLERS ON THE PATH OF LIFE). Being reunited is perceived as life paths crossing (JOINT ACTIVITIES IN LIFE ARE TREADING THE SAME ROAD), while separation entails starting to tread different paths (SEPARATION OF CLOSE PEOPLE IS STARTING TO TREAD DIFFERENT PATHS). These conceptual mappings have almost identical linguistic manifestations in English and Serbian (Liebknecht's and Eleanor's paths intersected vs. putevi su im se ponovo ukrstili or they would go down different roads vs. svako je otišao svojim putem).

(13) Buddeke, probably a German immigrant, was actually hired to tail Wilhelm Liebknecht, but on their American tours Liebknecht's and Eleanor's paths intersected.

(14) Best friends from the age of ten, now they would go down different roads.

(15) Putevi su im se ponovo ukrstili u Hjustonu, gde je radila kao nastavnica živeli su zajedno u istoj zgradi.

'Their paths intersected once again in Houston where she worked as a teacher $[\ldots]$.'

(16) U međuvremenu, svako je otišao svojim putem, a Isakovića je put preko Beograda doveo opet u Novi Sad.

'Meanwhile, everybody went down their own road [...].'

\section{LIFE IS HERE AND NOW; BIRTH IS ARRIVAL, DEATH IS DEPARTURE}

Metaphors related to birth and death can also be observed as realisations of the higher-order metaphor CHANGE OF STATE IS CHANGE OF LOCATION, since being alive and being dead are states (Özçalişkan 2003a: 199). Thus, "arrival (in)to life marks the beginning of a journey, where the person leading the life becomes a traveller", while "the point at which the journey ends is the departure point for death" (Özçalişkan 2003a: 198). In our examples in both languages, birth and death, as the starting and the end point on the path of life, are conceptualised as a person's arrival at a location and departure from it, whereby life is observed as "the deictic centre of the motion" (Özçalişkan 2003a: 198), yielding the conceptual metaphor LIFE IS HERE (Özçalişkan 2003a). The reference point is "this world", i.e. the visible, material reality in which one arrives at birth and which he/she departs at death.

The linguistic manifestations of the BIRTH IS ARRIVAL metaphor include verbs denoting arrival at a destination. A baby's time in the womb during pregnancy is denoted as travelling towards this world, which is manifested in the meaning of the Serbian phrase dete na putu. The same correlation is also established in 
English, manifested by a similar expression, the baby's on the way, which, however, does not contain the analysed lexemes.

(17) Plenty of babies come too soon after the wedding.

(18) I'd like to sort things out before baby arrives.

(19) Bio sam se već i oženio, dete na putu, a ona sve sluša. 'I was married already, and with a baby on the way [...].'

(20) Mladi su ga rodili. Po sedamnaest su imali kada je došao na svet. 'They were young when they had him. They were only seventeen when he arrived.'

(21) Edvard je probio led, i nešto manje od godinu dana posle njega stigli su blizanci, dve devojčice.

'Edward was the first, and less than a year later came the twins, two girls.'

Since birth is conceptualised as arrival into "this world", the only real world known to people, death is dominantly structured as departure from "this" world to "another" world, unknown to people (DEATH IS DEPARTURE), with other reference points, largely drawing on metonymy (otići sa ovog sveta).

(22) $[\ldots]$ many of those who didn't go to an early grave with some infection or other departed this life with a putrid liver.

(23) Dva sina, kojima me je Elvira obdarila, otišla su sa ovog sveta posle kratke bolesti.

'My two sons $[\ldots]$ departed this world after a short illness.'

\section{LIFE EVENTS ARE LOCATIONS ON THE PATH OF LIFE}

As argued elsewhere (Katz and Taylor 2008), the concept of life is not necessarily structured by the JOURNEY metaphor, but it is expected to be evoked "when people are primed to think of the course of life tied to a time dimension" (Katz and Taylor 2008: 151). The conceptualisation of life as a journey is thus closely related to the conceptualisation of time: "[t]he human lifespan represents an interval delimited by an onset, birth, and an offset, death" (Evans 2004: 109), which subsumes other intervals, for example, "beginning and completing primary or secondary school, matriculation at and graduation from university, and embarking on a career and retirement" (Evans 2004: 109). These intervals can be further divided into the beginning and end of the year or the academic term or starting to work for a new employer, leaving for the next one etc. (Evans 2004). In our 
examples, in both languages, important life events are structured as a series of intervals which are locations on the path of life.

The first point on this path is birth, the starting point of life's journey, while death is construed as the final point, i.e. the end of the journey (go to eternity, doći do kraja života). In Serbian, this final path point may also be conceptualised as a container (ići u smrt). In between, there are other important events, e.g. developmental periods (childhood, maturity), conceptualised as intermediate points on a person's path through life, sequenced accordingly from the past into the future.

(24) Religion is an integral part of its complex culture, and a complicated array of ceremonies and rituals cover every stage of a person's life, from birth to death.

(25) The mastery of a musical instrument, the ability to interpret notes, [...] are all central to a child's needs in the transition from babyhood through adolescence to maturity.

(26) This document purports to carry out the last mortal wish of the testator, except that he will probably go to eternity without being entirely sure that the document he signed actually said what he wanted $[\ldots]$.

(27) Od rođenja do smrti.

'From birth to death.'

(28) Postoje ljudi koji, došavši do kraja života i pošto su svakog dana činili iste stvari, pogledaju unazad i učini im se kao da nisu ni bili na ovome svetu.

'There are people who, when they come to the end of life, [...] look back and it seems as if they were not present in this world.'

(29) Po arapskim svedočanstvima, neke žene su dobrovoljno išle u smrt na pogrebu muža.

'[...] some women voluntarily went into their death at their husband's funerals.'

The transition from one phase of life to another is structured as passing through intermediate points on the path. This construal is based on the activity path structure, in which "mastery of each activity is depicted as a location (sub-destination) on a path, and the activities are located on the path in the order in which they have to be mastered" (Moore 2014: 387). Thus, people may metaphorically move through maturity phases (pass from childhood to adulthood). Attendance of different levels of education is accordingly construed as the journey from primary school to university, implying passage through various points on the path. The metaphorical movement may at the same time entail actual physical motion towards an educational institution and "moving" along the path of life, i.e. progress 
towards a new educational phase, with the institution where education takes place being frequently metonymically related to its location (I went away to university, kada dete krene u školu).

(30) In all pre-industrial societies children pass from childhood to adulthood by a "rite of passage"; there is virtually no in-between stage.

(31) I went away to university and made some new friends, and John and I finished.

(32) I već sutradan, kada dete krene u školu, slična scena će se ponoviti. '[...] when the child goes to school, the same scene will repeat itself.'

(33) Samo su srećnici mogli ići na školovanje isključivo u tadašnji Sovjetski Savez.

'Only the lucky ones were able to go to college in the former USSR.'

\section{CAREER IS A LOCATION/CAREER IS A PATH/CAREER IS A JOURNEY}

The structuring of a career as another major life event on the path of a moving person was prominently featured in the collected examples. Similar to life itself, a career is structured as a location with an entry and exit point through which a person pursuing a career moves from the beginning until the end (CAREER IS A LOCATION).

(34) All through his career he's had the ability to lead and inspire and he's really got through to our players and conveyed that.

(35) U poslednje vreme naša slavna balerina dosta je prisutna u zavičaju, ponajviše zbog „Čudesnog mandarina“ Bele Bartoka, koji kao da je njena sudbina - prati je kroz čitavu karijeru.

'Lately, our famous ballet dancer is often present around her home town, mostly because of the Miraculous Mandarin by Bela Bartok, which is her destiny - it has followed her through her entire career.'

In both languages, career is also conceptualised as a path within the path of life. Similar to the conceptual mapping CLOSE PEOPLE IN LIFE ARE TRAVELLERS ON THE SAME PATH, people who work together are experienced as co-travellers whose paths may cross at a particular moment in the career, while the separation of people who previously worked together is conceptualised as the divergence of their paths (just as in the case of life in general, when the separation of close people is structured as starting to tread different paths). Career role models are construed as people who travel or have travelled the same path as the trajector (this mapping was manifested by our lexemes only in the case of Serbian, ex. 41). 
(36) A typical career path might be a young European starting in the hotel industry as a management trainee [...] then progressing from, say, a major hotel chain through the food and beverage side to a management position at the top end of the leisure market.

(37) When their paths crossed years later at Manchester United, Morgan admits that he 'thought the world of The Doc [...]'.

(38) Torvill and Dean go in separate directions after setting the ice alight in their spectacular shows $[\ldots]$.

(39) Moja karijera je jedna duga i trnovita staza, sreća mi nikada nije bila pratilja, pa sam često ostajao apsolutno sam i otpisan.

'My career is a long and thorny path $[\ldots]$ '

(40) Grupa se sredinom 2006. raspala, a njeni članovi [...] otišli su različitim putevima.

'[...] the members of the group went their separate ways.'

(41) Tako je Stefanova krenula stazom Šveđanke Pije Kramling, verovatno zbog toga što procenjuje da se više isplati biti u timu šahista.

'So Stefanova pursued the path of the Swede Pia Cramling [...].'

As indicated by previous studies, the mapping CAREER IS A JOURNEY is a well-developed submetaphor of the LIFE IS A JOURNEY mapping and a career is observed as a separate journey within the journey of life. There are numerous linguistic manifestations of this metaphor in the excerpted examples. Different professions are conceptualised as locations on a career path, and the choice of a profession entails movement towards and arrival at a particular location. The profession is construed as a container (go into physics, otići u advokaturu), and, in Serbian, frequently a group of people who practice a profession are metonymically related to the profession itself (ići $u$ vodoinstalatere).

(42) The reason I went into physics and what I try to inculcate is that the ideas themselves are interesting.

(43) Oko 1.000 sudija napustilo pravosuđe, a većina je otišla u advokaturu. 'Around 1,000 judges left the judiciary, and the majority went into lawyers.'

(44) Ne znamo sudijinu reakciju kad je vidio predmet, ali lako je moguće da se sjetio majčinih riječi da je bolje da ide u vodoinstalatere nego u sudije. '[...] it is better to go into plumbers than into judges.' 
Progress in the career is structured as the distance covered during movement along the path, with certain positions being specific landmarks on a career path.

(45) Born and educated in the city [...] Miss Forbes was considered to have exceptional abilities and was expected to go far.

(46) Talentovani Beograđanin je korak po korak gradio svoju karijeru da bi stigao ovako daleko [...].

'The talented Belgrade citizen built his career step by step to come this far $[\ldots]$.'

(47) Od 1954. do 1976. prošao je put od zvanja asistenta do redovnog profesora na Akademiji (kasnije Fakultetu) likovnih umetnosti.

'From 1954 to 1976 he passed the path from a Teaching Assistant to the Full Professor at the Academy of Arts.'

The final phase of the career, retirement, is construed as the arrival of the moving agent at the final destination on a career path. There is a slight difference in the linguistic manifestation of this mapping in English and Serbian, since in English retirement is structured as a final point on the path (go to retirement), and in Serbian as a container (otići u penziju).

(48) I'm interested in making this job last as long as possible but I don't think I want to go to retirement.

(49) Međutim, mi u ovom trenutku nemamo ni tačan broj nastavnika koji će otići u penziju kroz pet godina.

'However, at the moment we do not have the exact number of teachers who will go into retirement in five years.'

\subsection{LIFE IS A MOVING ENTITY}

The analysis of the collected examples has shown that, both in English and Serbian, life itself, death and career may be moving entities. Some of the established metaphorical mappings in this case rely on the JOURNEY scenario, with the progress of life or a career structured as their movement along a series of points towards a destination. Particularly important in this respect is the direction of motion, which may be from the past into the future or from the future into the past.

In the first case, the way life or career unfolds is construed as their movement from the past into the future, as in the following examples.

(50) If I hold on to these things they go, and if I let go of them they go, and so my life goes. 
(51) Naseby was not pleased at the way his career had gone.

(52) Život uvek ide svojim putem, sa više ili manje našeg ličnog doprinosa.

'Life always goes its own way [...].'

(53) Dr Branko Tošović je bio istaknuti lingvista čija je karijera išla svojim prirodnim tokom na Univerzitetu u Sarajevu, do izbijanja rata u Bosni i Hercegovini.

'Dr Branko Tosovic was a prominent linguist whose career went its natural way at the University of Sarajevo [...].'

Life and career may move in another direction, from the future into the past. In this case, life's progress is construed as the arrival to and departure from the location which denotes the present moment, which is also the location of a person at the moment of existence.

(54) The extended family were all moving over to make room for each other once this fleeting life had passed.

(55) Raičković prihvatio načelo da je ironija nedovoljna i nesposobna da govori o životu koji je prošao.

'Raickovic accepted the creed that irony is insufficient and incapable of expressing the life that had passed.'

When career moves from the future into the past, its beginning is structured as the appearance of a moving career at the person's current location, which stands for the present moment (however, this example was found in the English corpus only).

(56) As Worrell's career came at the same period, the stature he acquired both as a man and a leader gave added impetus and credibility to the black independence movement, especially as cricket is such an important part of Caribbean life.

In Serbian, there is an additional case of two metaphorical movers on the same path, death and the person. The person is moving towards the future by its very existence, while death comes from the past and catches up with him/her, which inevitably entails the end of life (HUMAN EXISTENCE IS A RACE WITH DEATH).

(57) Pa i ako bi me smrt stigla pre nego što do kraja ostvarim svoj naum, najveći deo bio bi urađen i moj saradnik - fotograf bi okončao posao.

'Even if death caught up with me before I managed to accomplish my idea $[\ldots] . '$ 
Another set of examples demonstrates that life is also construed as an entity located in a human body that leaves it at the moment of death. The departure of life entails the arrival of death, which takes the person away, giving rise to complementary mappings LIFE IS A TRAVELLER THAT LEAVES THE PERSON/HUMAN BODY AT THE MOMENT OF DEATH, DYING IS DEATH'S ARRIVAL TO THE HUMAN BODY.

(58) There are certain spells that can prevent the life departing from a body [...].

(59) Well, he is a man, he is mortal, death comes to us all, [...].

(60) Dok mi nađemo ono što nam treba život ode od nas [...]. 'Until we manage to find what we need, life departs from us [...].'

(61) I smrt je došla ne kao kraj života, već zato što je pokojnik bio Jevrejin. 'And death came not as the end of life, but because the deceased was a Jew.'

\section{Discussion and concluding remarks}

Our analysis has shown that in both English and Serbian a variety of metaphors relying on the experience with motion along a path play a vital role in the structuring of life and the related concepts of birth, death, important periods in life, education, career etc. This was expected if we bear in mind the previous studies, but the obtained findings gain more relevance since the analysis was performed on randomly selected data from representative corpora. Different components of motion along the path are relied upon in both languages as a person metaphorically moves through life as a location or a container, along life as a road, where life choices entail taking different paths, parents are guides and close people in life are co-travellers. Life is a journey or a series of intervals from the starting point (birth) to the ending point (death), while the locations in between stand for important life events, and education or career may be separate journeys with their own locations. This once again confirms the statement that LIFE IS A JOURNEY is "a composite mapping drawing from a range of related and mutually coherent metaphors" (Evans and Green 2006: 300). In both English and Serbian, life is metaphorically also here and now, especially in the case of the conceptualisation of birth and death. Additionally, life may be structured as a moving entity in both languages. The conceptual mappings in this case may rely on the JOURNEY scenario, when the progress of life or career is conceptualised as their passage through certain points on the path, in both directions. Life may also be a traveller that leaves the person/human body at the moment of death, with dying expressed as death's arrival at the human body. The linguistic manifestations of these correspondences are fairly similar in the two observed languages. The only major difference is the presence of the conceptual mapping HUMAN EXISTENCE IS A RACE WITH DEATH in Serbian, which is not found in English in any of the analysed lexemes. 
Thus, as was shown for English and Turkish by Özçalişkan (2003a), there are inverse moving person/moving life metaphor instances in English and Serbian as well. According to Lakoff and Johnson (1999: 149), dual metaphors, such as moving time and the moving observer are "minimally differing variants of one another", or "figure-ground reversals". However, the choice of the metaphorically moving entity may affect causation. It can be argued that in the case of a moving person, he/she may be ascribed a more active role than when life is observed as a moving entity on its own, which the person living the life has less control over. Further investigations in this field could thus focus on the frequency of occurrence of the moving agent and moving life instances in representative corpora, in hopes of revealing the dominant pattern of conceptualising various aspects of life, and, additionally, control over it, in different languages.

It has also been noted that the direction of motion of the entities from the domain of LIFE conceptualised via the components of motion along the path depends on the moving entity in question. If the person living the life is construed as metaphorically moving, then the motion takes place from the past into the future. When the moving entity is life or a career, the direction of motion may be from the past towards the future, when the progress entails reaching points further on along the path. Also, the direction of motion may be from the future into the past, when progress implies the arrival of the entity from the future and its departure from the given point into the past. Therefore, in the instance of life moving, a different direction of motion implies a different conceptualisation of the given events.

There are certain limitations to this kind of research, first of all, pertaining to the number of selected path components and, consequently, the number of lexemes used for the analysis. Future research might concentrate on the more diverse aspects of the path, some of which have already been mentioned in the literature. This, in turn, might reveal the presence of more diverse conceptual mappings and point to further similarities and differences between the languages. Another important aspect would be to take into account the quantitative perspective and explore whether there are any statistical differences in the occurrence of the major established metaphorical patterns for conceptualising LIFE. In other words, a quantitative analysis of the corpora examples might reveal the presence or the absence of the preference of one language for one of the possible ways of structuring life via PATH metaphors. Furthermore, it might be possible to compare English and Serbian with respect to the frequency of occurrence of each of the established conceptual mappings. This bears additional relevance since the qualitative analysis indicates that there are high inter-language similarities pertaining to the conceptualisation of LIFE via path components.

Notwithstanding, in the current scope, this study has shown that a corpus-based cognitive-semantic analysis using the material of two languages may further confirm and complement knowledge about the "well-known" mappings mentioned in the literature, as well as shed light on certain new patterns and open up pathways for their investigation. 


\section{Notes}

1 The British National Corpus (BNC) consists of 100 million words included in the samples of written and spoken language. The written part is taken from regional and national newspapers, journals, academic books and popular fiction, letters and memoranda, school and university essays et al., while the spoken part includes the transcriptions of informal conversations and spoken language collected in different contexts.

2 The Corpus of the contemporary Serbian language 2013 of the Faculty of Mathematics of the University of Belgrade contains around 122 million of words and includes samples from the written language, such as literary texts, science and popular science, newspaper and magazine articles, web sites, administration etc.

3 Death may be conceptualized in other ways, e.g. DEATH IS SLEEP, DEATH IS REST, DEATH IS NIGHT, DEATH IS A REAPER (Lakoff and Turner 1989). Molek-Kozakowska (2016) notes that in popular science reporting death may also be framed in terms of the unknown.

\section{References}

Cameron, Lynne and Alice Deignan (2003) Combining large and small corpora to investigate tuning devices around metaphor in spoken discourse. Metaphor and Symbol 18(3), 149-160.

Deignan, Alice (1999) Corpus-based research into metaphor. In: Cameron, Lynne and Graham Low (eds.) Researching and Applying Metaphor. Cambridge: Cambridge University Press, 177-199.

Eschenbach, Carola, Ladina Tschander, Cristopher Habel and Lars Kulik (2000) Lexical specifications of paths. In: Freksa, Christian, Wilfried Brauer, Cristopher Habel and Karl F. Wender (eds.) Spatial Cognition II. Berlin: Springer, 127-144.

Evans, Vyvyan (2004) The Structure of Time. Language, Meaning and Temporal Cognition. Amsterdam and Philadelphia: John Benjamins.

Evans, Vyvyan and Melanie Green (2006) Cognitive Linguistics: An Introduction. Hillsdale, NJ and Edinburgh: Lawrence Erlbaum Associates and Edinburgh University Press.

Filipović, Luna (2007) Talking About Motion. A Crosslinguistic Investigation of Lexicalization Patterns. Amsterdam and Philadelphia: John Benjamins Publishing Company.

Gibbs, Raymond (2007) Why cognitive linguists should care more about empirical methods. In: Gonzalez-Marquez, Monica, Irene Mittelberg, Seana Coulson and Michael J. Spivey (eds.) Methods in Cognitive Linguistics. Amsterdam and Philadelphia: John Benjamins, 2-18.

Grady, Joseph (2007) Metaphor. In: Geeraerts, Dick and Herbert Cuyckens (eds.) The Oxford Handbook of Cognitive Linguistics. Oxford: Oxford University Press, 188-213.

Inkson, Kerr (2002) Thinking creatively about careers: the use of metaphor. In Peiperl, Maury, Michael Arthur and N. Anand (eds.) Career Creativity: Explorations in the Re-Making of Work. Oxford: Oxford University Press, 15-34.

Johansson Falck, Marlene (2010) Are metaphorical paths and roads ever paved? Corpus analysis of real and imagined journeys. Review of Cognitive Linguistics 8(1), 93-122.

Johansson Falck, Marlene (2016) 'What trajectors reveal about time metaphors: Analysis of English and Swedish'. International Journal of Corpus Linguistics 21(1), 28-47.

Johnson, Mark (1987) The Body in the Mind: the Bodily Basis of Meaning, Imagination, and Reason. Chicago: The University of Chicago Press.

Katz, Albert N. and Tamsen E. Taylor (2008) The journeys of life: Examining a conceptual metaphor with semantic and episodic memory recall. Metaphor and Symbol 23(3), 148-173.

Klikovac, Duška (2004) Metafore u mišljenju i jeziku. Beograd: Biblioteka XX vek.

Klikovac, Duška (2006[2000]) Semantika predloga: Studija iz kognitivne lingvistike. Beograd: Filološki fakultet. 
Kövecses, Zoltan (2008) Conceptual metaphor theory. Some criticisms and alternative proposals. Annual Review of Cognitive Linguistics 6(1), 168-184.

Lakoff, George (1987) Women, Fire and Dangerous Things: What Categories Reveal About the Mind. Chicago: Chicago University Press.

Lakoff, George (1993) The contemporary theory of metaphor. In: Ortony, Andrew (ed.) Metaphor and Thought, $2^{\text {nd }}$ ed. New York: Cambridge University Press, 202-251.

Lakoff, George and Mark Johnson (1999) Philosophy in the Flesh. The Embodied Mind and Its Challenge to Western Thought. New York: Basic Books.

Lakoff, George and Mark Johnson (2003[1980]) Metaphors We Live By. Chicago and London: The University of Chicago Press.

Lakoff, George and Mark Turner (1989) More Than Cool Reason: A Field Guide to Poetic Metaphor. Chicago: The University of Chicago Press.

Lakusta, Laura and Barbara Landau (2005) Starting at the end: The importance of goals in spatial language. Cognition 96(1), 1-33.

Lakusta, Laura and Barbara Landau (2012) Language and memory for motion events: Origins of the asymmetry between goal and source paths. Cognitive Science 36(3), 517-544.

Matlock, Teenie, Michael Ramscar and Lera Boroditsky (2005) On the experiential link between spatial and temporal language. Cognitive Science 29(4), 655-664.

Molek-Kozakowska, Katarzyna (2016) Framing disease, ageing and death in popular science journalism. Brno studies in English 42(1), 49-69.

Moore, Kevin Ezra (2014) The two-Mover hypothesis and the significance of "direction of motion" in temporal metaphors. Review of Cognitive Linguistics 12(2), 375-409.

Özçalişkan, Seyda (2003a) Metaphorical motion in crosslinguistic perspective: A comparison of English and Turkish. Metaphor and Symbol 18(3), 189-228.

Özçalişkan, Seyda (2003b) In a caravanserai with two doors I am walking day and night: Metaphors of death and life in Turkish. Cognitive Linguistics 14(4), 281-320.

Özçalişkan, Seyda (2005) Metaphor meets typology: Ways of moving metaphorically in English and Turkish. Cognitive Linguistics 16(1), 207-246.

Papafragou, Anna (2010) Source-goal asymmetries in motion representation: Implications for language production and comprehension. Cognitive Science 34(6), 1064-1092.

Pragglejaz Group (2007) MIP: A Method for identifying metaphorically used words in discourse. Metaphor and Symbol 22(1), 1-39.

Radden, Günter (1996) Motion metaphorized: The case of coming and going. In: Casad, Eugene H. (ed.) Cognitive Linguistics in the Redwoods: The Expansion of a New Paradigm in Linguistics. Berlin and New York: Mouton de Gruyter, 423-458.

Radden, Günter (2004) The metaphor TIME AS SPACE across languages. In: Baumarten, Nicoel, Claudia Böttger, Markus Motz and Julia Probst (eds.) Übersetzen, Interkulturelle Kommunikation, Spracherwerb und Sprachvermittlung - das Leben mit Mehreren Sprachen: Festschrift für Juliane House zum 60. Geburtstag. Bochum: AKS-Verlag, 225-238.

Silaški, Nadežda (2011) Metaphors and euphemisms - the case of death in English and Serbian. Filološki pregled XXXVIII (2), 101-114.

Silaški, Nadežda and Tatjana Đurović (2014) One step forward, two steps back: Conceptualizing Serbia's EU accession in Serbian and EU discourse. In: Musolff, Andreas, Fiona MacArthur and Giulio Pagani (eds.) Metaphor and Intercultural Communication. London and New York: Bloomsbury, 185-201.

Smith-Ruig, Theresa (2008) Making sense of careers through the lens of a path metaphor. Career Development International 13(1), 20-32.

Steen, Gerard (2007) Finding Metaphor in Grammar and Usage: A Methodological Analysis of Theory and Research. Amsterdam and Philadelphia: John Benjamins.

Stefanowitsch, Anatol and Stefan Th. Gries (eds.) (2006) Corpus-based Approaches to Metaphor and Metonymy. Berlin and New York: Mouton de Gruyter. 
Vesić Pavlović, Tijana (2014) Where do our roads run? Fictive motion in English and Serbian. In: Paunović, Zoran (ed.) ELLSEE proceedings. Beograd: Filološki fakultet, 143-154.

Vesić Pavlović, Tijana (2015) Metaforička preslikavanja slikovne sheme PUTANJE u engleskom i srpskom jeziku. PhD Thesis. Beograd: Filološki fakultet.

Zwarts, Joost (2005) Prepositional aspect and the algebra of paths. Linguistics and Philosophy 28(6), 739-779.

\section{Sources}

British National Corpus (BNC). Available at: http://corpus.byu.edu/bnc.

Corpus of contemporary Serbian language 2013 of the Faculty of Mathematics, Belgrade University. Available at http://korpus.matf.bg.ac.rs.

Tijana Vesić Pavlović is an Assistant Professor at the Faculty of Mechanical Engineering, University of Belgrade, Serbia. She graduated from the Faculty of Philology, University of Belgrade, Serbia, where she also obtained her MA and PhD in linguistics. Her fields of interest include cognitive semantics, contrastive analysis, discourse analysis and ESP. She has authored several articles in journals and conference proceedings.

Address: Dr Tijana Vesić Pavlović, Faculty of Mechanical Engineering, University of Belgrade, Kraljice Marije 16, Belgrade, Serbia. [email: tvesic@mas.bg.ac.rs] 